\title{
BACTERIAL COLONIZATION OF THE ILEUM IN RATS WITH OBSTRUCTIVE JAUNDICE
}

\author{
Ivana Duval-Araujo ${ }^{1}$; Arnaldo Santos Leite ${ }^{1}$; Guilherme Veloso Diniz ${ }^{1}$; Arnaldo Alves Silva ${ }^{1}$; Ricardo Yukio Okawa ${ }^{1}$; \\ Dulciene Maria de Magalhães Queiroz ${ }^{2}$; Andy Petroianu ${ }^{1}$
}

${ }^{1}$ Departmento de Cirurgia, Escola Médica da Universidade de Minas Gerais, Belo Horizonte, MG, Brasil; ${ }^{2}$ Laboratório de Pesquisa em Bacteriologia, Escola Médica da Universidade Federal de Minas Gerais, Belo Horizonte, MG, Brasil

Submitted: March 09, 2004; Returned to authors for corrections: January 11, 2006; Approved: July 18, 2007.

\section{SHORT COMMUNICATION}

\begin{abstract}
Qualitative and quantitative alterations in ileal flora during obstructive jaundice and the role of bile salts were evaluated in rats. Obstructive jaundice was associated with bacterial overgrowth in the ileum. This effect may be due to the reduced concentration of bile salts, since dietary supplementation reduced the small bowel aerobic bacterial flora.
\end{abstract}

Key words: Cholestasis; bile salts; intestinal flora.

Patients with obstructive jaundice have an increase in perioperative complication rate related to endotoxemia, impaired host immunity and activation of inflammatory response. Sepsis, bleeding, deficient wound healing, renal and liver dysfunction is also observed in those patients $(6,22,24)$.

The absence of bile salts in the gastrointestinal tract may be related to a greater bacterial colonization by aerobic gram negatives aerobic flora and consequently increased amounts of endotoxins that are absorbed into portal circulation $(16,17,22)$. Portal endotoxemia is usually observed in jaundiced patients, and the small bowel is well established as the origin of these endotoxins $(4,10,20)$. The antibacterial effect of bile salts have an important role in the control of enteric flora $(4,11)$ and gut motility $(7,8,15,19)$. Several authors describe the prophylactic use of bile salts and its protective effect on renal function, and reduction of portal and systemic endotoxemia. However, other investigators did not confirm those benefits $(12,15,18)$. The present study was performed in order to evaluate the influence of bile salts on ileum bacterial colonization during obstructive jaundice.

We studied fifty Holtzman rats (250-450 g) divided into four groups according to the following procedures: I $(n=13)$, sham operation: only laparotomy and laparorrhaphy; II ( $n=13)$, sham operation and oral administration of bile salts during six days ( $6.5 \pm 1.5 \mathrm{mg} / \mathrm{kg} /$ day $) ; \mathrm{III}(\mathrm{n}=11)$, ligation and section of the common bile duct; IV ( $\mathrm{n}=13)$, ligation and section of the common bile duct and oral administration of bile salts during six days $(5.8 \pm 1.3 \mathrm{mg} / \mathrm{kg} / \mathrm{day})$.

All surgical procedures were performed under general inhalatory anesthesia with ether and aseptic conditions. The bile salts were diluted in the water offered to the animals.

The rats were killed with an overdose of ether on the seventh postoperative day. A segment of one centimeter was aseptically withdrawn from the ileum at 10 centimeters from the caecum. This segment was introduced into a tube containing $9.0 \mathrm{ml}$ of sterile saline solution and stirred (10-1 dilution). Successive dilution was performed up to 10-9. Two ml of each dilution were put into $18 \mathrm{ml}$ of melted and cooled Tryptone Soy Agar and stirred on a Vortex during one minute. These homogenous samples were spread on sterile Petri dishes and carefully swirling. The Petri dishes were incubated at $37^{\circ} \mathrm{C}$ for 48 hours, and considered results between 10 and 100 colonies/plate.

Qualitative cultures were prepared using BHI blood agar and MacConkey agar with the sample of the 10-1 dilution. The colonies were identified by Gram staining and biochemical tests (13).

The quantitative results were compared through Student's t test, and the qualitative results were compared by Chi-square test. $P$ values $<0.05$ were considered significant.

*Corresponding Author. Mailing address: Rua Bento Mendes Castanheira n 121 apto 102. CEP: 31260-270 - Belo Horizonte, Minas Gerais. E-mail: idaraujo@medicina.ufmg.br 
The quantitative results showed a mean of $18.4 \pm 9.6 \times 108$ colonies/plate in group I, $24.7 \pm 10.9 \times 108$ colonies/plate in group II, $33.0 \pm 21.4 \times 109$ in group III and $32.1 \pm 8.6 \times 108$ in group IV. There was a significant increase in aerobic bacterial colonization in group III when compared to the others groups (p-value < 0.05). No significant differences were observed in group IV when compared to groups I and II (Table 1).

The most common species isolated in all groups were Escherichia coli. The amount of Gram positive bacteria was reduced in groups III and IV when compared to other groups, but this difference was not statistically significant significant differences were demonstrated. The number of Pantoea agglomerans, however, was significatively increased in group IV (p-value 0.04, Table 1).

Sepsis due to intestinal translocation of bacteria is the major cause of perioperative morbidity and mortality in patients with obstructive jaundice. Absence of bile in the intestinal tract is considered to be a factor inducing alteration in gut flora, and may be related to increase in the gut content of endotoxins as well their translocation into systemic circulation $(12,18)$.

Translocation of bacteria and endotoxins have been demonstrated in some experimental studies, but the underlying mechanism is unclear. It can be associated to alterations in intestinal flora and gut barrier failure $(18,19,21,23)$. The increase in gut flora associated with absence of bile salts is less studied (9). Our results indicate that obstructive jaundice cause bacterial proliferation in rat ileum. Bile salts probably play a pivotal role in controlling aerobic ileum bacteria in obstructive jaundice due to direct effect upon bacteria (5) or by controlling enteric motility (8). Absence of bile salts in gut lumen is associated with reduced intestinal motility that could lead to bacterial overgrowth as in this study. We also demonstrated that dietary supplementation with bile salts caused modification in ileal microflora. This finding supports the hypothesis of a direct effect of bile salts upon aerobic gut microflora or the association of these two events.

In this study oral administration of bile salts to jaundiced rats prevent bacterial overgrowth, suggesting a potential beneficial role of administration of bile salts to jaundiced patients. The number of colonies in jaundiced animals using bile salts was not different from the control group, similar to that described previously in rats with choledocovesical fistula $(2,3,14)$.

In conclusion, obstructive jaundice promotes an increase in bacterial flora, and a dietary supplementation with bile salts revert this effect with modification in aerobic bacterial species of these flora.

\section{ACKNOWLEDGEMENTS}

Financial support: CNPq, FAPEMIG, PRPQ-UFMG.

\section{RESUMO}

\section{Colonização bacteriana do íleo de ratos com obstrução biliar}

As alterações qualitativas e quantitativas da flora ileal na obstrução biliar e o papel dos sais biliares foram avaliados em

Table 1. Average total count and bacterial species of aerobic bacteria isolated from the ileum rats.

\begin{tabular}{lcccc}
\hline \multirow{2}{*}{ BACTERIA } & \multicolumn{4}{c}{ GROUP } \\
\cline { 2 - 5 } & $\mathrm{I}(\mathrm{n}=13)$ & $\mathrm{II}(\mathrm{n}=13)$ & $\mathrm{III}(\mathrm{n}=11)$ & $\mathrm{IV}(\mathrm{n}=13)$ \\
\cline { 2 - 5 } & $\mathrm{n}(\%)$ & $\mathrm{n}(\%)$ & $\mathrm{n}(\%)$ & $\mathrm{n}(\%)$ \\
\hline Total number of aerobic bacteria per ml of ileal wash $\left(\mathrm{X} 10^{8}\right)$ & $18.4 \pm 9.6$ & $24.7 \pm 10.9$ & $330 \pm 214$ & $32.1 \pm 8.6$ \\
\hline Escherichia coli & $7(41.2)$ & $10(62.5)$ & $8(66.7)$ & $5(38.4)$ \\
Providentia rettigeri & $1(5.9)$ & $1(6.2)$ & - & - \\
Proteus mirabilis & $2(11.8)$ & - & - & - \\
Proteus vulgaris & $1(9.9)$ & - & - & - \\
Pantoea agglomerans & $1(9.9)$ & $1(6.2)$ & - & $4(30.8)$ \\
Enterobacter cloacae & $1(5.9)$ & - & - & - \\
Enterobacter aerogenes & - & - & $1(8.3)$ & $2(15.4)$ \\
Salmonella sp. & - & - & $1(8.3)$ & $1(7.7)$ \\
Enterococcus sp. & $4(23.4)$ & $4(25.1)$ & $2(16.7)$ & $1(7.7)$ \\
\hline Total number of isolated bacteria* & $17(100)$ & $16(100)$ & $12(100)$ & $13(100)$ \\
\hline
\end{tabular}

*Total numbers refer to total of bacteria isolated in any group. There were rats with two or more bacterial species/genera isolated;

I - Sham operation. II - sham operation and bile salts orally. III - common bile duct ligation. IV - common bile duct ligation and bile salts. 
ratos. Em animais com obstrução biliar houve aumento da população ileal. Esse efeito é provavelmente causado pela ausência de sais biliares no lúmen ileal, uma vez que em animais cuja dieta foi suplementada com sais biliares houve redução da flora ileal.

Palavras-chave: colestase; sais biliares; flora entérica.

\section{REFERENCES}

1. Andrade, M.A.C.; Duval-Araujo, I. (1991). Preparo pré-operatório e complicações pós-operatórias em icterícia obstrutiva. Folha médica, 102(5), 159-161.

2. Burke, V.; Stone, D.E.; Beannen, J.; Gracey, M. (1977). Effects of biliary diversion on intestinal microflora in the rat. J. Med. Microbiol., 10(2), 241-244.

3. Cahill, C.J. (1983). Prevention of postoperative renal failure in patients with obstructive jaundice. Br. J. Surg., 70(10), 590-595.

4. Clements, W.D.; Parks, R.; Erwin, P.; Halliday, M.J.; Barr, J.; Rowlands, B.J. (1996). Role of the gut in the pathophysiology of extrahepatic biliary obstruction. Gut, 39(4), 587-583.

5. Deitch, E.A.; Sittig, K.; Li, M. Berg, R.; Specian, R.D. (1990). Obstructive jaundice promotes baterial translocation from the gut. Am. J. Surg., 159(1), 79-84.

6. Duval-Araujo, I.; Andrade, M.A.C. (1991). Morbidade e mortalidade pós- operatórias em icterícia obstrutiva. Arq. Bras. Méd., 65(8), 267-269.

7. Duval-Araujo, I.; Petroianu, A.; Oliveira Neto, J.E.; Sabino, L.O. (1996). Endotoxin-induced enteric hipomotility in jaundiced loops in vitro. Braz. J. Med. Biol. Res., 29(8), 995-999.

8. Duval-Araujo, I.; Petroianu, A.; Oliveira Neto, J.E.; Sabino, L.O. (1995). Influencia dos sais biliares na resposta motora de alcas isoladas a acetilcolina, em ratos. Rev. Assoc. Méd. Brás, 41(5), 325-328.

9. Erbil, Y.; Berber, E.; Ozarmagan, S.; Seven, R.; Eminoglu, L.; Calis, A.; Olgac, V.; Gürler, N. (1999). The effects of sodium deoxycholate, lactulose and glutamine on bacterial translocation in common bile duct ligated rats. Hepatogastroenterology, 46(29), 2791-2795.

10. Fletcher, M.S.; Westwick, J.; Kakkar, V.V. (1982). Endotoxin, prostaglandins and renal fibrin deposition in obstructive jaundice. Br. J. Surg., 69(10), 625-629.
11. Floch, M.H.; Gershergoren, W.; Elliot, S.; Spiro, H.M. (1971). Bile acid inhibition of the intestinal microflora - a function for simple bile acids? Gastroenterology, 61(2), 228-233.

12. Kuzu, M.A.; Kale, I.T.; Cöl, C.; Tekeli, A.; Tanik, A.; Köksoy, C. (1999). Obstructive jaundice promotes bacterial translocation in humans. Hepatogastroenterology, 46(28), 2159-2164.

13. Mac Faddin (1980), First Edition, Editora Medica Panamericana S.A., Viamonte, Buenos Aires.

14. Mallory, A.; Kern, F.; Smith, J.; Savage, D. (1973). Patterns of bile acids and microflora in the human small intestine. I Bile acids. Gastroenterology, 64(1), 26-33.

15. Nieuwenhuijs, V.B.; Van Dijk, J.E.; Gooszen, H.G.; Akkermans, L.M. (2000). Obstructive jaundice, bacterial translocation and interdigestive small-bowel motility in rats. Digestion, 62(1), 255-261.

16. Ogata, Y.; Nishi, M.; Nakayama, H.; Kuwahara, T.; Ohnishi, Y.; Tashiro, S. (2003). Role of bile in intestinal barrier function and its inhibitory effect on bacterial translocation in obstructive jaundice in rats. J. Surg. Res., 115(1), 18-23.

17. Pain, J.A.; Bailey, M.E. (1986). Experimental and clinical study of lactulose in obstructive jaundice. Br. J. Surg., 73:775-778.

18. Parks, R.W.; Stuart Cameron, C.H.; Gannon, C.D.; Pope, C.; Diamond, T.; Rowlands, B.J. (2000). Changes in gastrointestinal morphology associated with obstructive jaundice. J. Pathol., 192(10), 526-532.

19. Quraishy, M.S.; Chescoe, D.; Mullervy, J.; Coates, M.; Hinton, R.H.; Bailey, M.E. (1996). Influence of the gut microflora and of biliary constituents on morphological changes in the small intestine in obstructive jaundice. HPB Surg, 10(1), 11-20.

20. Ravin, H.A. (1969). Intestinal endotoxins and host resistence. Surg. Clin. North Am., 49(3), 583-587.

21. Reynolds, J.V.; Murchan, P.; Leonard, N.; Clark, P.; Keane, F.B.; Tanner, W.A. (1996). Gut barrier failure in experimental obstructive jaundice. J. Surg. Res., 62(1), 11-16.

22. Sheen-Chen, S.M.; Chau, P.; Harris, H.W. (1998). Obstructive jaundice alters Kupffer cell function independent of bacterial translocation. J. Surg. Res., 80(2), 205-209.

23. Welsh, F.K.; Ramsden, C.W.; MacLennan, K.; Sheridan, M.B.; Barclay, G.R.; Guillou, P.J.; Reynolds, J.V. (1998). Increased intestinal permeability and altered mucosal immunity in cholestatic jaundice. Ann. Surg., 227(2), 205-212.

24. Yang, Z.W.; Li, J.G.; Mao, X.G.; Sun, B.; Tong, Z.S.; Sun, H.Y.; Li, X.R.; Cong, Y.P. (2005). Effects of recombinant human growth hormone on intestinal translocation of bacteria and endotoxin in rats with obstructive jaundice. Hepatobiliary Pancreat. Dis. Int., 4(3), 445-449. 